\title{
The Legal Protection for Breach of the Marriage Promise for Women
}

\author{
Juliana S.Ndolu ${ }^{1}$, Adi Sulistiyono ${ }^{2}$, Mohammad Jamin ${ }^{3}$ \\ ${ }_{1.2 .3}$ Faculty of Law, Universitas Sebelas Maret, Surakarta, Indonesia \\ juliana21@student.uns.ac.id
}

\begin{abstract}
Cases of men breaching their promise to marry women following extra marital pregnancies often occur in Indonesian society and can be detrimental for women and children. However, the majority of cases cannot be prosecuted under the current legal arrangement. This paper aims to first analyze the legal arrangements for Breach of the Marriage Promise and second analyze the legal protection for women victimized by breach of the marriage promise from the perspective of Pancasila justice. This paper found that: first, the substance of the legal arrangements regarding breach of the marriage promise does not accommodate marital promises that have yet been announced to the public, causing such cases unable to be processed through both civil and criminal law. Second, Pancasila justice without discrimination respects human dignity. The 1945 Constitution is a concrete reflection of the values embedded in Pancasila justice. When portrayed using the 1945 Constitution and Law Number 7 of 1984 concerning the Elimination of Discrimination Against Women.
\end{abstract}

Keywords-Protection, Marriage, Women.

\section{INTRODUCTION}

Men breaching their promises to marry women often occurs in Indonesian society and are very detrimental to women. The report published by the National Commission on Anti-Violence Against Women stated that in 2018 there were 2,073 cases of dating violence. This number increased compared to 1,873 cases of dating violence in 2017[1]. According to Komnas Perempuan, dating violence also covers cases of breach of the marriage promise. Rumah Perempuan, a NonGovernment Organization (NGO) based in Kupang, East Nusa Tenggara noted that there were 30 cases of breach of the marriage promise in 2017.[2] Sanggar Suara Perempuan (SSP) in the South Central Timor District of East Nusa Tenggara noted that there were 21 cases of breach of the marriage promise.[3]

Information above found several similar things regarding cases of breach of the marriage promise. First, the reported cases of breach of the marriage promise were not capturing the actual number of cases on the field. The actual number of cases were even higher than the number of reported cases. Second, from all cases of breach of the marriage promise, none were able to be prosecuted through both civil and criminal court.

Article 58 of the Civil Code (Kitab UndangUndang Hukum Perdata/KUHPerdata) stated that cases of breach of the marriage promise can be processed in court when the men have publicly announced his marriage promise. While in most cases of breach of the marriage promise, such promises were not publicly announced; consequently, the cases cannot be processed under the Civil Code. Breach of the marriage promise is also not regulated under the Criminal Code. Incidences of breach of the marriage promise were harmful to women, children, and families. Having a single mother in the family would tarnish the reputation of the families. Cases of breach of marriage promise would also force women to become sole provider for their children. Single mother status in Indonesian society has a negative connotation. These children would also be affected by the negative stigma of being 'illegitimate children'. This situation creates injustice towards these women and children.

Pancasila as the state's vision and the source of law provides an assurance that the state has the responsibility to protect and provide justice for all citizens by ensuring the fulfilment of all their rights, including legal rights. In this context, the state should have the responsibility to provide such legal protection to women victims of breach of the marriage promise. Based on the aforementioned, this article would answer these following problems: 1) How is the legal arrangement and consequences of breach of the marriage promise defined within Indonesia's positive legal system, and 2) How is the legal protection towards women victims of Breach of the marriage promise defined in the perspective of Pancasila justice.

\section{RESEARCH METHOD}

This is a normative research that uses statute approach[4] to study and analyse the legal framework related to legal issues around breach of the marriage promise and conceptual approach[4] to examine the views, principles and concepts in legal studies that are relevant to the issues of breach of the marriage promise. 


\section{FINDINGS AND DISCUSSION}

\section{Legal Arrangement and Consequences of Breach of the marriage promise Within the Indonesia's Positive Legal System}

In Indonesia, marriage promise is explicitly governed in Article 58 of the Civil Code where "marriage promise does not create right to demand marriage before the judge, it also does not create right to demand compensation of cost, loss, and interests that resulted from failure to fulfill the marriage promise, all agreement for compensation in this regard is annulled. However, a public announcement of the marriage promise can serve as a basis to demand compensation of cost, loss, and interests based on real losses suffered by one party as a result of the other party's breach; in which loss of profit cannot be calculated. This demand expired within 18 months of the aforementioned announcement."

Based on, article 58 of the Civil Code, it is clear that not all breach of the marriage promises can be prosecuted under the Civil Court, only cases in which the marriage promise has been publicly announced can be processed. In this sense, a notice of the marriage promises needs to be filed to the Civil Registration Office and followed by a marriage announcement. This article does not formulate men's marriage promise that led to extramarital pregnancies. Consequently, in such cases, women do not possess the right to make demands for any material and immaterial losses.

Another article that is often used as a basis to prosecute cases of broken promises to marry is Article 1363 Civil Code that stated, "any act against the law, that resulted in loss to others, creates a responsibility for the person responsible to provide compensation for the loss." According to Rosa Agustina, "act against the law" can be defined as actions that are: 1) contrary to perpetrator's legal responsibility, 2) contrary to other's subjective rights, 3) contrary to morality, and 4) contrary to compliance, carefulness, and caution.[5] Wiryono Projodikoro defined action against the law as action that resulted in a shock in social life, that can occur not only when there is a direct violation of legal regulations in the society.[6] Therefore, definition of such action will depend on the severity of the shock created. Even though an action will only break moral, religious, or decency codes; this action still require strong prevention measures, as in actions that are a direct violation of the law.

Wiryono Prodjodikoro's opinion is complementary to that of Rosa Agustina. In the context of an action, Wiryono Prodjodokoro expanded the definition of against the law to also comprises actions that break religious codes. This expansion relates with the first principle of the Pancasila: "Belief in the One and Only God". All actions against the law are therefore an act against religious code, because in principle all religion preach kindness. This opinion also stress that law is sourced from religious values. In the context of relation between legal subjects, especially from the side of the person whose right is violated, Wirjono Prodjodikoro expanded definition covers not only breach to individual rights, but also explicitly covers the social sphere through the phrase "shock in social life." In order to be able to use Article 1365 of the Civil Code on actions against the law to demand marriage promise, one must still refer to Article 56 of the Civil Code on marriage promise. This means that the marriage promises need to be publicly announced. In the case of breach of the marriage promises that led to extramarital pregnancy, the woman cannot demand the fulfilment of the promise as long as the promise were not made public.

According to A. Ridwan Halim legal consequence is all consequences that happens from any legal action conducted by legal subject towards legal object, or any other consequences resulted from certain event that is defined or considered as a legal consequence by corresponding law. This legal consequence in turn created legal subject's rights and responsibility. In other words, legal consequence is a consequence resulting from a legal event.[7] While a legal event is an event in the society that moved a particular legal regulation so the provisions in it are realized.[8] More specifically, we can say that if an event happened in a society, and the event is consistent to what is described in a legal regulation, than the regulation is applicable to the event. Legal event is categorized into two: legal event resulting from a legal subject's action (human conduct) and legal event not resulting from a legal subject's action (not human conduct).[9]

Based on the aforementioned expert opinions, we can conclude that legal consequence has a close connection with legal action and legal event. Legal consequence can happen if the consequence of a particular legal action is defined by law. As such, the event resulting from that action is categorized as legal event. Referring to the aforementioned expert opinions, then cases of breach of the marriage promise can be categorized as legal action that resulted in a legal event and thus having a legal consequence is breach of the marriage promise that has been announced to the public according to article 58 of the Civil Code. This situation is confirmed by data from NGOs. NGOs that are assisting victims of breach of the marriage promise in East Nusa Tenggara like Yabiku, SSP, Rumah Perempuan, and Rumah Harapan. [10] have all reported that all assisted cases of breach of the marriage promise cannot be processed legally. From 2015-2019, SSP has assisted 143 cases of Breach of the marriage promise and none of the cases could be processed legally.[11]

Another legal consequence of breach of marriage promise affects the children born of extramarital pregnancy. J. Satrio thinks that within the scope of Indonesia's positive law, children's status are categorized into two category: legitimate, which refers to children that are born of legal marriage, and illegitimate, which refers to children that are born 
outside legal marriage.[12] In Law No. 1 of 1974 on Marriage, which has been replaced by Law No. 6 of 2019, article 43 stated that children born outside legal marriage only have civil relationship with their mothers and the families of their mother. This regulation was then changed through the Constitutional Court Decision No. 46/PUU-VIII/2010, which governs the children's civil relationship with their fathers, if the relationship can be legally or scientifically proven. This means as long as no legal or scientific effort was made to prove the relationship is conducted, children born following a breach marriage promise will not have any civil relationship with their fathers.

This further result in another legal consequence towards the children. The birth certificate of such children will only state the mothers' name, without the name of the biological father. Legally, children have the right to know who their parents are, as Article 7 of Law No. 23 of 2003, which has been replaced by Law No. 35 of 2014 on Child Protection. Another violation of Law No. 7 on Child Protection is the unfulfillment of children right to be raised and cared for by their own parents. Another side effect includes negative 'illegitimate child' stigma of the children by the community.

\section{Legal Protection for Women Victims of Breach of the marriage promise from the Perspective of Pancasila Justice}

Justice is an ideal condition that every human longs for. It is a basic moral concept that upholds human dignity. Justice in Indonesian context cannot be separated from the concept of Pancasila justice. Franz Magnis-Suseno has examined each Pancasila's principle to define how Pancasila defined justice and argued as follows: 1) Belief in One and Only God. This principle essentially stresses on the belief and obedience to God. 2) Just and Civilized Humanity. Justice is a precondition to just inter-human relationships which respects others' dignity. 3) The Unity of Indonesia. Unity of Indonesia can only happen with the basis of Justice. 4) Democracy that is Led by Wisdom in Consultation/Representation. This principle defined population sovereignty and democracy (through consultation) as a demand for justice. 5) Social Justice for All Indonesian Citizen. Social justice refers to a state where all Indonesian citizens are experiencing justice in aspects of politics, legal, economy, social, culture, and ideology.

Based on Franz Magnis-Suseno's point of view, we can redefine Pancasila justice as honouring others' dignity without differentiating sex, ethnicity, race, religion, and social status. All citizens must receive justice in aspects of politics, legal, economy, social, culture, and ideology. Respect for others' dignity is the teaching of all religion. Just and civilized humanity is one of the principles for citizen's human rights protection and is a just characteristic owned by Pancasila as the country's philosophy and ideology. Just and civilized humanity is the basis of human rights protection through humanizing human in a civilized manner without diminishing their rights.

Referring to Pancasila, Notonegoro stated that justice is the fulfilment of all things that have constituted the rights in living together as the nature of the relationship between one another, the fulfilment of each of the rights in the relationship between one and the other as mandatory.[13] Justice essentially means compulsory fulfilment of human rights in life; prioritization of responsibility over rights; and fulfilment of such rights and responsibilities, which include: (1) the relationship between the state and citizens, hereinafter referred to as distributive justice, (2) the relationship of citizens with the state referred to legal justice, and (3) relationship between fellow citizens referred to as commutative justice. Notonegoro stressed the importance of fulfilling responsibility over rights. The concept of prioritizing responsibility over rights is a concept that is aligned with the integral paradigm that prioritizes public interests over individual interests. The emphasis on the importance of prioritizing responsibility reminds us that our rights are limited by the rights of others. The exercise of responsibility takes precedence in the context of respecting the rights of others. Justice demands that people treat each other according to their rights and responsibilities.

Notononegoro offered legal instruments as a tool to encourage the creation of justice. Their thinking is aligned with the thoughts of Gustav Radbruch and John Rawls. Gustav Radbruch that stated the value of justice is the "material" that must shape the content of the rule of law, while the rule of law is the "form" that must protect the value of justice. [14] John Rawls also said something similar, the principle of justice must guide us in developing policies and laws to correct injustices in the basic structure of certain societies. [15]

The inability to legally process cases of breach of marriage promise is a portrait of the lack of respect for the dignity of women. Victims' rights to be treated as dignified humans have been violated. Limitations on the legal substance summarized in Article 58 of the Civil Code have an impact on legal injustice for women and children. Corrections to arrangements regarding marriage promises are needed to ensure justice for victims. Law is an instrument to achieve justice for citizens, for that law must be positioned as a protector for the fulfilment of citizens' rights. Legal protection according to Andi Hamzah is the protection covering the whole rules or norms and values regarding an aspect of community life that aims to achieve peace and prosperity of the community.[16]

The concept of protection according to Andy Hamzah emphasizes that the rules to protect its citizens include values and norms aimed at realizing peace and welfare of the people. [17] Fitzgerald quoted Salmond's theory of legal protection that law aims to integrate and coordinate various interests in society. The legal interest is to take care of human rights and interests, so the law has the highest authority to determine human interests 
that need to be regulated and protected. [18] According to Satjipto Rahardjo, legal protection is to provide protection for human rights that have been harmed by others and that protection is given to the community so that they can enjoy all the rights granted by law.

Legal protection refers to behaviour or legal action carried out by the government by giving up the rights and obligations of legal subjects and implemented based on the applicable law in Indonesia. Legal protection arises because of legal relationships. Legal relations (Rechtbetrekking) are interactions between legal subjects that have legal relevance or have legal consequences (the arising of rights and obligations).[19] This understanding emphasizes that legal protection arises because of the behaviour and relationships between legal subjects

Based on the concept of legal protection delivered by Fitzgeral, Satjipto Rahardjo, Andy Hamzah and Dewi Rahayu legal protection can be reformulated as the state's responsibility to ensure that all citizens can enjoy their rights to achieve peace and prosperity, which is realized through the creation of regulations governing the interests and behaviours between legal subjects in the relationship between community members, and community members and the government. Regulations made must be based on respect for human dignity and human rights. The state must ensure that in implementing these regulations, the state must represent the interests of the people whose dignity and human rights are violated.

Based on the concept of legal protection above, the analysis will focus on the legal protection of women in Indonesia. Using 1945 Constitution, which is the constitution that holds the highest position in the hierarchy of laws in Indonesia, as lens. The 1945 Constitution is sourced from Pancasila, as the highest legal source in Indonesia. This means that the regulation of citizens' constitutional rights in the 1945 Constitution is a concrete form of the Pancasila values of justice.

The 1945 Constitution provides legal guarantees to every citizen. Article 28 paragraph 3 of the 1945 Constitution states "All citizens holds the same position in front of the law and government". Article 28 paragraph 3 emphasizes that all Indonesian citizens regardless of ethnicities, race, religion, or gender differences have the same rights without discrimination. The 1945 Constitution guarantees that "Every person has the right to be free from discriminatory treatment on any grounds and has the right to get protection against such discriminatory treatment." Assurance through the principle of discrimination becomes an important basis, to determine whether any provisions or actions are discriminatory. Discrimination on the basis of sex, therefore, can be categorized as a violation of the constitutional rights of Indonesian citizens.

In the framework of fulfilling the rights as mentioned above, there must be an awareness that social, cultural, economic diversity will affect everyone's legal access. Therefore, a special policy is needed that can accommodate the diversity so that citizens' rights can be. Assurance of the fulfilment of rights in the 1945 Constitution is contained in Article 28H Paragraph (2) of the 1945 Constitution that "Every person has the right to get special facilities and treatment to obtain equal opportunities and benefits in order to achieve equality and justice".

Women are one of the groups in society who need special policies. As stated by Sulistiawati Irianto that in the Indonesian context Justice for Disadvantaged Groups, including the poor, women and children still needs to be advocated. [20] In various schools of study, women agree that the existence of women as part of a disadvantaged group is not only because of their sexuality as a woman, but is closely related to issues of race, class, colonialism, and naturism (Tong, 1998; Harding, 1987; Moore 1998). The main explanation is due to the lack of women's power in the relations between herself and the people around her, including her husband, relatives (customary authority) to the power elite in government.

In the context of legal protection against women, the Government of Indonesia has ratified the Convention on Elimination of All Forms of Discrimination Against Women (CEDAW) through Law Number 7 of 1984 concerning the Elimination of All Forms of Discrimination Against Women. CEDAW is an International Human Rights Agreement that specifically regulates women's rights. Article 15 explains four state obligations to eliminate legal discrimination against women, including granting women equal rights with men before the law. The CEDAW Ratification confirms that: 1) The principle of equality before the law between women and men is upheld by the Indonesian government 2) The principle of anti-discrimination against women does not conflict with Pancasila and the 1945 Constitution 3) The state is obliged to harmonize various laws and regulations in Indonesia so as not to discriminate against women.

Through the concept of legal protection for women, it can be concluded that the 1945 Constitution expressly recognizes equal rights between men and women before the law as legal subjects. The 1945 Constitution rejects discrimination on the basis of sex against women. The commitment to eliminate discrimination against women is not only limited to the country level but also at the global level through the ratification of CEDAW as stipulated in Law Number 7 of 1984 concerning the Elimination of All Forms of Discrimination Against Women.

Prof. Adi Sulistyono in his introduction to the book Law as the Commander of the Economy (Hukum Sebagai Panglima Ekonomi) stated that the law should be a torch to translate the spirit of the constitution as well as being a guiding light for the good. [21] When we analyse article 58 of the Civil Code using the 1945 Constitution as the highest source of law in Indonesia and Law No. 7 of 1984 concerning the Elimination of Discrimination Against Women, it can be concluded that article 58 of the Civil Code is an example of a law that does not become a torch of light in translating the 
values and spirit of the constitution, to protect the dignity of women victims of breach of marriage promise. The explanation is as follows: 1) Article 58 of the Civil Code concerning marriage promises is contradicting Article 27 of the 1945 Constitution, Article 2 Letters C and F of Law No. 7 of 1984 that regulates the principle of equality before the law for all Indonesian citizens, both women and men. 2) The enactment of Article 58 of the Civil Code shows that the state has not provided adequate protection to women through policy revisions as stipulated in Article 4 paragraph 2 and Article 5 Letter (e) of Law No. 7 of 1984. 3) Article 58 concerning marriage promises is contradicting the rights of women and children, such as their right to form a family; children's right to growth and development; their right to personal protection of the family, honour, dignity, and property; the right to obtain special treatment as regulated in Article $28 \mathrm{~B}$ paragraph 1 and 2, Article $28 \mathrm{G}$ paragraph 1, Article 28 $\mathrm{H}$ paragraph 2, Article $28 \mathrm{~J}$ paragraph 1.

\section{The Importance of Legal Regulation to Protect Women Victim of Broken Promises to Marry}

Using the concept of Pancasila justice in capturing legal protection to victims of broken promises to marry, it can be concluded that legal protection to victims of breach of the marriage promise remains very weak. Breaking marriage promise is proof that women are not treated as dignified humans. The most basic rights have been violated. Violations of rights that occur not only against women's rights but also children's rights. The principle of child protection in the sense of the best interests of the child is violated. The child's right to know his parents and get parental care has been violated.

Currently, cases of breach of the marriage promise that cannot be processed legally are resolved through customary mechanisms with the aim of getting justice for victims, including the children. Customary settlement is usually done by giving customary fines to the perpetrators. But such efforts have been criticized because the customary settlement sometimes does not fulfil the victims' sense of justice. This criticism was raised by victim assistance NGOs that assisted victims in the customary resolution process.

The state has sought legal protection for victims of breach of the marriage promises. The breach of the marriage promise is categorized as a criminal offense in the draft of Criminal Code (Rancangan Kitab UndangUndang Hukum Pidana/RKUHP). Article 418 of the RKUHP reads "A man who is engaged in sexual relationship with a woman who is not his wife with the woman's consent under the promise to marry, then breached that promise because another guile is sentenced to a maximum of 4 (four) years imprisonment or a maximum of category III fines." In addition to imprisonment, lawmakers should consider adding: 1) Obligation of the perpetrator to finance a Deoxyribonucleic Acid (DNA) test, 2) Obligation of the perpetrator to pay for child support until the child is independent, 3) Include the father's name on the birth certificate. These efforts are concrete forms of legal protection in order to provide a sense of justice for women and children.

\section{IV.CONCLUSION}

Cases of breach of the marriage promise following extramarital pregnancy are common in the community and are very detrimental to women and children, both socially and economically. However, the substance of legal arrangements regarding breach of the marriage especially Article 58 of the Civil Code, does not accommodate marriage promises that have not been publicly announced, causing cases of breach of the marriage promise cannot be processed legally in both Civil and Criminal Courts. Pancasila justice emphasizes the importance of respecting human dignity and nondiscrimination; justice must be enjoyed by citizens in legal, social, political, and cultural aspects; as well as the importance of respecting human rights. Pancasila as a legal source is more concretely stated in the 1945 Constitution, which is the highest constitution. Using the 1945 Constitution and Law Number 7 of 1984 in capturing cases of breach of the marriage promise, it can be concluded that: a) the law cannot be processed due to violations of promises to marry are contrary to the principle of equality before the law for all citizen, both men and women b) cases of breach of marriage promise are a violation to the rights of women and children Currently the government has sought legal protection for victims of breach of the marriage promise to marry. The breach of the marriage promise is categorized as a criminal offense in the Draft of Criminal Code Article 418.

\section{REFRENCES}

[1] Komnas Perempuan annually publishes a public report on cases of Violence Against Women in Indonesia, "The data were taken from Komnas Perempuan's Report,” Jakarta, 2017.

[2] E. N. T. that works in providing assistance to women survivors of violence. Rumah Perempuan, is an NGO based in Kupang, "Every year Rumah Perempuan produced a public report on their assistance activities. The data was taken from the report publis," Kupang, 2017.

[3] Sanggar Suara Perempuan (SSP), "is an NGO based in South Central Timor, East Nusa Tenggara that works on empowering women and children, as well as providing legal assistance for them. The data were taken from SSP's report published in December 2018 by SSP i," South Central Timor, 2018.

[4] H. Salim and E. S. Nurbani, Penerapan teori Hukum Pada Penelitian Tesisi dan Disertasi. Jakarta: Rajawali Pers, 2017. 
[5] R. A. in Namira, "Perbuatan Melawan Hukum Atas Tindakan Tidak Mengakui Hak Anak Luar Kawin oleh Ayah Biologis (Study Kasus Keputusan Nomor 953/K/Pdt/1998)," Universitas Indonesia, 2010.

[6] W. P. in B. Untung, Hukum dan Etika Bisnis. Yogyakarta: Andi Offset Publishing, 2012.

[7] A. R. Halim and D. D. Machmuddin, Pengantar Ilmu Hukum Sebuah Sketsa. Bandung: Refika Aditama, 2016.

[8] Soeroso, Pengantar Ilmu Hukum. Jakarta: Sinar Grafika, 2011.

[9] P. Syarifin and Z. Chumaidy, Pengantar Ilmu Hukum. Bandung: Pustaka Setia, 1998.

[10] R. H. is an N. that provides assistance to survivors of gender-based violence and human Trafficking, This organization was formed by the Sinode of Gereja Masehi Injili di Timor (GMIT). .

[11] Position Paper, Yayasan Sanggar Suara Perempuan, Memperkuat Kerjasama Untuk Penghapusan Kekerasan Terhadap Perempuan Anak. 2020.

[12] J. S. in B. Edyar, "Status Anak Luar Nikah Menurut Hukum Positif dan Hukum Islam," J. Huk. Islam, vol. 1, no. 2, 2016.

[13] N. in Y. Herawati, "Konsep Keadilan Sosial Dalam Bingkai Sila Kelima Pancasila," $J$. Paradig., vol. 18, no. 1, 2014.

[14] G. R. in T. B. L., S. Y. N., and H. M. Y, Teori Hukum; Strategi Tertib Manusia Lintas Ruang dan Generasi. Yogyakarta: Genta Publishing, 2013.

[15] R. Jhon, A Theory of Justice-Teori Keadilan; Dasar- Dasar Fisafat Politik Untuk Mewujudkan Kesejahteraan Sosial Dalam Masyarakat. Yogyakarta: Pustaka Pelajar, 2019.

[16] A. H. R. Andi, Fitriono, and Sarwon, "Legal Protection of Lurik Art Conservation Through Intellectual Property Rights In Klaten Regency," Yust. J. Huk., vol. 8, no. 2, pp. 354-364, 2019.

[17] P. M. Hadjon, Perlindungan Hukum Bagi Rakyat Indonesia, Sebuah Study tentang PrinsipPrinsipnya, Penangannya oleh Pengadilan Dalam Lingkungan Peradilan Umum dan Pembentukan Peradilan Administrasi, M2Print. First PrintSpecial Edition, 2007.

[18] F. in Satjipto, R. in T. Astuti, and Handayani, "Mewujudkan Keadilan Gender melalui Perlindungan Hukum Terhadap Perempuan," Rechtstaat Nieuw Journal, vol. 1, no. 1, pp. 18-29, 2016.

[19] D. Rahayu and S. Fatoni, "Commercial Sexual Exploitation of Children: An Effort of Handling and Legal Protection," J. Huk. Yust. Univ. Sebel.
Maret, vol. 8, no. 2, pp. 334-353, 2019.

[20] S. Irianto, "Menuju Pembangunan Hukum ProKeadilan Rakyat, this article is a part of doctorate inauguration speech titled 'Meretas Jalan Keadilan Bagi Kaum Terpinggirkan dan Perempuan: Suatu Tinjauan," Socio-Legal, pp. 9-10, 2019.

[21] Sulistiyono and A. M.Rustamadji, Hukum Ekonomi Sebagai Panglima. Masmedia Buana Pustaka, First Print, 2009. 